\title{
Dexamethasone action on caudal fin regeneration of carp Cyprinus carpio (Linnaeus, 1758)
}

\author{
Ochandio, BS. ${ }^{a}$, Bechara, IJ. ${ }^{b}$ and Parise-Maltempi, PP. ${ }^{a *}$ \\ aDepartamento de Biologia, Instituto de Biociências, Universidade Estadual Paulista "Júlio de Mesquita Filho" - UNESP, \\ Av. 24A, 1515, CEP 13506-900, Rio Claro, SP, Brazil \\ ${ }^{b}$ Laboratório de Histofisiologia e Histopatologia Experimental em Ectotérmicos, Departamento de Histologia e \\ Embriologia, Instituto de Biologia, Universidade Estadual de Campinas - UNICAMP, CP 6109, \\ CEP 13083-970, Campinas, SP, Brazil \\ *e-mail: parise@rc.unesp.br
}

Recepted: October 1, 2013 - Accepted: December 13, 2013 - Distributed: May 31, 2015

(With 17 Figures)

\begin{abstract}
Studies have demonstrated that the prolonged use of corticoids can delay the healing process, affecting re-epithelialization, neovascularization and collagen synthesis. As the fins of teleost fish contain a large amount of collagen, the aim of the present study was to investigate the effect of dexamethasone (anti-inflammatory and glucocorticoid steroid widely used in the treatment of rheumatic diseases) during the regeneration process in the caudal fin of specimens of carp (Cyprinus carpio). For such, two glass aquaria were used - one for a group of fish treated with dexamethasone (Henrifarma) in a $20 \mathrm{mg} / \mathrm{L}$ concentration and the other for the control group. The caudal fins were amputated transversally and fish remained in their respective aquaria until regeneration occurred. Samples of regenerating fins were collected on days $1,2,4,6,8$ and 10 after amputation. The fins in the control group regenerated normally and grew within the expected in time course. The fins in the group treated with dexamethasone were significantly smaller in comparison to the control group at every evaluation time. Thus, it was possible to verify that, at this concentration of dexamethasone, the regeneration of the caudal fins was delayed, but not completely inhibited. The results show that the caudal fin is a good model for histological studies on regeneration and the action of drug toxicity, but it's also of great importance the interaction with further studies for a better knowledge and understanding of all the changes in all the phases.
\end{abstract}

Keywords: dexamethasone, caudal fin, tissue regeneration, collagen, fish.

\section{Estudo da ação da dexametasona na regeneração da nadadeira caudal de Cyprinus carpio (carpa) (Linnaeus, 1758)}

\section{Resumo}

Estudos mostram que corticóides usados por longos períodos podem atrasar o processo de cicatrização, influenciando na reepitelização, na neovascularização e na síntese do colágeno. Os constituintes das nadadeiras dos peixes teleósteos contêm grande quantidade de colágeno e assim o objetivo do presente trabalho foi estudar o efeito da dexametasona (um antiinflamatório e glicocorticóide esteróide bastante utilizado no tratamento de doenças reumáticas) durante o processo regenerativo das nadadeiras caudais das carpas (Cyprinus carpio). Para isso, foram montados dois aquários de vidro, um para o grupo controle e outro para o grupo tratado com a dexametasona (Henrifarma) na concentração de $20 \mathrm{mg} / \mathrm{L}$. Os peixes distribuídos nesses aquários tiveram suas nadadeiras caudais amputadas transversalmente e permaneceram nos respectivos aquários para que ocorresse a regeneração. Foram feitas coletas das nadadeiras em regeneração em intervalos de 1, 2, 4, 6, 8 e 10 dias após a amputação. Foi observado que nos peixes do grupo controle, as nadadeiras regeneraram normalmente e cresceram o esperado em cada intervalo de tempo. No entanto, foi verificado que nos peixes do grupo tratado com dexametasona, em cada intervalo analisado, as nadadeiras regeneradas dos peixes expostos à droga eram menores que a medida das nadadeiras dos peixes do grupo controle. Assim, foi possível verificar que, nessa concentração de dexametasona, a regeneração das nadadeiras caudais foi mais lenta, mas não ocorreu a total inibição da regeneração. Dessa forma, os resultados comprovam que a nadadeira caudal é um bom modelo para estudos histológicos sobre a regeneração e a ação da toxicidade de drogas, mas, também, é de grande importância a interação com estudos mais aprofundados para se conhecer e compreender melhor todas as alterações em todas as fases.

Palavras-chave: dexametasona, nadadeira caudal, regeneração tecidual, colágeno, peixe. 


\section{Introduction}

The anatomy of the teleost fish fins is relatively simple and there are no fundamental morphological or cellular differences among the dorsal, pectoral, pelvic, anal and caudal fins of the same fish (Goodrich, 1904; Prenant, 1936; Blanc, 1947; Grassé, 1958; Lanzing, 1976; Becerra et al., 1983), demonstrating that the development of the fins has been kept the same for over 400 million years of evolution (Mabee et al., 2002). In contrast to the different position, the patterning of the fins remains linked. In most teleosts, fin consist mainly of skeletal elements (rays) covered by skin. These rays originate at the base of the fin and extend distally toward the outer edge (Arita, 1971; Mabee et al., 2002). Each ray is known like lepidotrichium and each lepidotrichium is made up of a pair of elongated and curved structures arranged bilaterally (demi-rays), which are subdivided longitudinally into lepidotrichial hemisegments separated by joints (Arita, 1971), except for the radius side of the caudal fin that does not suffer bifurcation (Akimenko et al., 2003). Two bilateral hemi-segments surround an intra-segmental region, in which nerve bundles, blood vessels and loose conjunctive tissue are found. The entire intra-lepidotrichial conjunctive tissue, which holds the hemi-segments in place, as well as the skeletal components of the fins contain a large amount of collagen (Becerra et al., 1983). Extending from the distal portion of each lepidotrichium toward the outer edge of the fin, there is a conglomerate of small and thin spicules called actinotrichia, which sustain the edge of the fin membrane. Actinotrichia are hyperpolymerized macrofibrils composed of a protein similar to collagen, denominated elastoidin (Becerra et al., 1983; Krukenberg, 1985).

In cases of injury, some species of teleost have the ability to regenerate fins and completely regain function (Yoshinari et al., 2009). This complex regeneration mechanism involves similar events to those that occur in amphibians and begins within the first hours following an injury (Murciano et al., 2007). A number of studies in the literature report the development and histological study of the fins regeneration in teleosts. (Goss and Stagg, 1957; Kemp and Park, 1970; Geraudie, 1977, 1978; Weis and Weis, 1980; Santamaria et al., 1992; Geraudie et al., 1995; Becerra et al., 1996; Böckelmann and Bechara, 2004; Böckelmann and Bechara, 2007; Böckelmann et al., 2010). The fundamental phases of the fin regeneration process are healing, beginning with the formation of an apical epidermal cap, development of mesenchymal cells mass (blastema), the differentiation of these cells, synthesis and deposition of extracellular matrix, growth and morphological restoration (Geraudie et al., 1995; Becerra et al., 1996, 2000; Böckelmann and Bechara, 2004, 2007; Böckelmann et al., 2010).

According to Bechara et al. (2000), the glycocorticoid steroid dexamethasone, which is widely used in different inflammatory processes (Reynolds, 1996), can affect the synthesis and organization of collagen during the fins regeneration of the teleost fish. Other authors state that the prolonged use of corticoids can delay the healing process, affecting re-epithelialization, neovascularization and collagen synthesis (Gupta et al., 1999; Talas et al., 2002).

The aim of the present study was to assess the antiinflammatory action on the regenerative processes of the fins of the Cyprinus carpio (Linnaeus, 1758), which is rich in collagen and has an exceptional natural regeneration capacity.

\section{Material and Methods}

\subsection{Materials}

Cyprinus carpio fingerlings with approximately seven centimeters in length, purchased from a fish farm located in town near Campinas (state of São Paulo, Brazil), were kept at the Fish Bioassay Laboratory of the Department of Histology and Embryology, Biology Institute, Universidade Estadual de Campinas (Brazil) in tanks with clean, dechlorinated water at a temperature of $25^{\circ} \mathrm{C}$ and constant aeration. Two glass aquaria with the same conditions (clean, de-chlorinated water, $25^{\circ} \mathrm{C}$, constant aeration) were used for the experiment.

\subsection{Methods}

Previous assays were carried out to test the best amount of dexamethasone to be employed and describe regeneration under the action of the corticoid. From experiments, with dexamethasone in concentration of $25 \mathrm{mg} / \mathrm{L}$, a concentration of $20 \mathrm{mg} / \mathrm{L}$ was selected. After a one-week acclimatization period, with daily change of water the tank from by other clean dechlorinated, one aquarium received $20 \mathrm{mg} / \mathrm{L}$ of dexamethasone and the other was maintained with only water as the control group. After 24 hours, the fishes were anesthetized with benzocaine (1:10000) (SYNTH, Brazil) and the caudal tails were transversely amputated in the dorsal-ventral direction three $\mathrm{mm}$ from the muscle peduncle of the tail (Becerra et al., 1996). The fish were returned to their respective tanks for the occurrence of regeneration until the end of the experiment. Every day all water in each aquarium was exchanged for clean water and $20 \mathrm{mg} / \mathrm{L}$ of dexamethasone was added to the experimental aquarium.

On days 1, 2, 4, 6, 8 and 10 after amputation, five specimens were removed from the experiment, anesthetized and the regenerated region of the fins was measured with the naked eye using a sheet of paper with a millimeter grid.

The fins were then excised, placed in Bouin's aqueous solution for six hours and fixed in paraffin for analysis of histological sections of $5 \mu \mathrm{m}$ in a light microscope with hematoxylin-eosin, Masson's trichrome and Picrosiriushematoxylin of three colorings for better distinction of tissue organization.

\subsection{Statistical analysis}

Twenty-five histological cuts of five fish from each evaluation time were randomly selected and photographed in a conventional photomicroscope coupled to the Image Pro-Plus image analysis program (version 4.1.12; Media Cybernetics, USA) and analyzed morphologically. The results were obtained with the statistical comparison 
between the averages of the fins before amputation and the average measurements of the areas in each time interval evaluated, employing analysis of variance (ANOVA). Followed by Tukey comparison test. The significance level was $5 \%(\mathrm{p}<0.05)$. The INSTAT v 2.01 statistical program (GraphPad, San Diego, CA, USA) was used for all analyses.

Table 1. Mean and standard deviation of the regenerated region length of caudal fin from Cyprinus carpio in the control and treated group at each evaluation time (observed by naked eye).

\begin{tabular}{clc}
\hline \multirow{2}{*}{$\begin{array}{c}\text { Days following } \\
\text { amputation }\end{array}$} & \multicolumn{2}{c}{ Treatments } \\
\cline { 2 - 3 } & \multicolumn{2}{c}{ Regenerated region (cm) } \\
\cline { 2 - 3 } Control & Dexamethasone \\
\hline 4 & $0.10 \pm 0$ & $0.05 \pm 0.04$ \\
6 & $0.17 \pm 0.06$ & $0.06 \pm 0.02$ \\
8 & $0.30 \pm 0$ & $0.19 \pm 0.06$ \\
10 & $0.41 \pm 0.09$ & $0.23 \pm 0.05$ \\
\hline
\end{tabular}

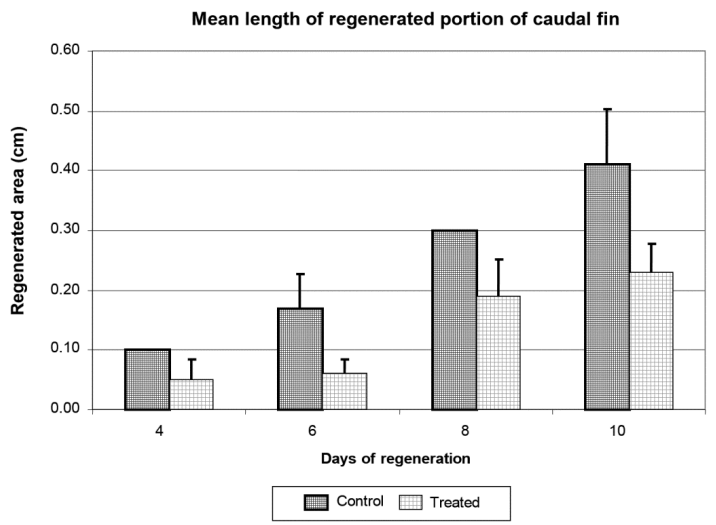

Figure 1. Development regenerated area of Cyprinus carpio caudal fin (observed with naked eye) from day 4 to 10 after amputation in control group and group treated with dexamethasone $(20 \mathrm{mg} / \mathrm{L})$.

\section{Results}

The measurements taken by the naked eye revealed in present experiment using dexamethasone concentration of $20 \mathrm{mg} / \mathrm{L}$ differences in size of the regenerated regions between the control and experimental groups, what was not measurable in the first and second days after amputation. Measures of regenerated fins were made from the 4th day of regeneration on. The mean values are displayed in Table 1 and Figure 1.

The results obtained from the analysis of all histological sections are described below with the best images collected.

The histological analysis on days 1 and 2 after amputation revealed that the lateral epidermal cells of the portion that did not suffer injury migrated to the amputated area in the first hours following injury, forming an apical epidermal cap in both groups. There were no statistically significant differences between groups in the early regeneration process (Figures 2 and 3 ).

On day 4 , the fins in the group treated with dexamethasone began to exhibit significantly delayed regeneration in comparison to those in the control group. Just below the epidermis occurred the formation of the blastema, as evident by a darker mass of conjunctive cells in both groups. However, in the group treated with dexamethasone, the blastema developed less and the cells of the epithelium basal layer were not yet cylindrical, which is an essential characteristic for the synthesis of the basal membrane (Figures 4 and 5).

On day 6, the fins in the control group exhibited normal regeneration. The epithelium and conjunctive tissue had grown in the proximal-distal direction. The cells of the epithelium basal layer were cylindrical. The cells of the blastema (now called scleroblasts) were arranged side-byside forming in single row and had begun the synthesis of the lepidotrichial matrix in the region directed toward the basal membrane of the epithelium (Figures 6, 7 and 8). The fins in the group treated with dexamethasone also exhibited cylindrical cells in the basal layer of the epithelium involved in the synthesis of the basal membrane, but in
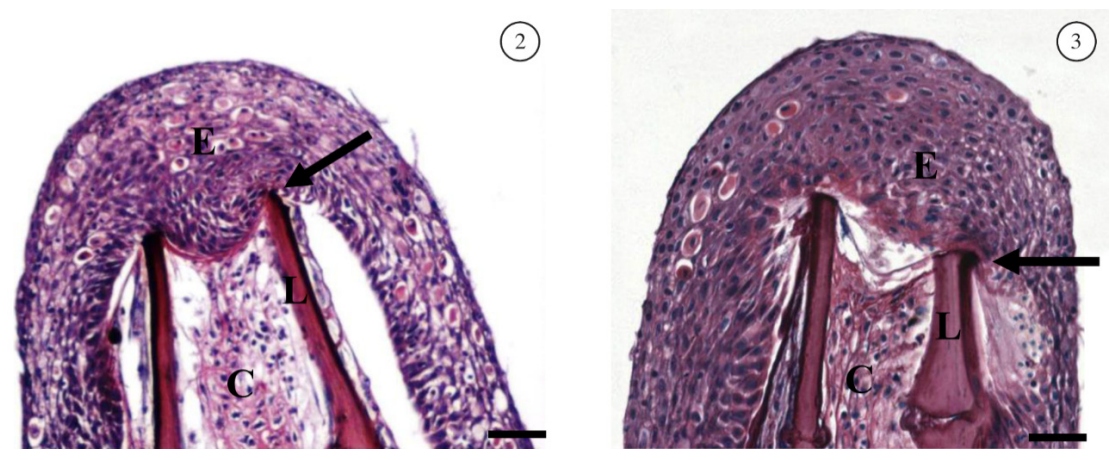

Figures 2 and 3. Longitudinal sections of distal region of Cyprinus carpio caudal fin one day after regeneration. 2. Picrosiriushematoxylin stained sections of control group. Black arrow: amputation site; L: old lepidotrichium (non-regenerated); E: epidermis in regeneration; observe apical epidermal cap; $\mathrm{C}$ : non-regenerated conjunctive tissue. 3. Picrosirius-hematoxylin stained sections of treated group with dexamethasone $(20 \mathrm{mg} / \mathrm{L})$. Black arrow: amputation site; L: old lepidotrichium (nonregenerated); E: epidermis in regeneration; observe apical epidermal cap; C: non-regenerated conjunctive tissue; Bar: $30 \mu \mathrm{m}$. 
a different way from that observed in the control group. Moreover, the lepidotrichial matrix had not yet begun to be synthesized and the development of the conjunctive tissue was affected, demonstrating inhibition of the regeneration process (Figures 9 and 10).

On days 8 and 10, there were no longer large histological differences between groups (Figures 11, 12, 13 and 14). On day 8 after amputation, the lepidotrichia in the control group had grown in length and width to virtually their full size. The same did not occur in the group treated with dexamethasone, but the regeneration process was clearly underway. On the 10th day regenerative process, the actinotrichia, which sustain the edge of the fin membrane had appeared in both groups (Figures 15 and 16), demonstrating that regeneration was not inhibited, but merely delayed in the group treated with dexamethasone.
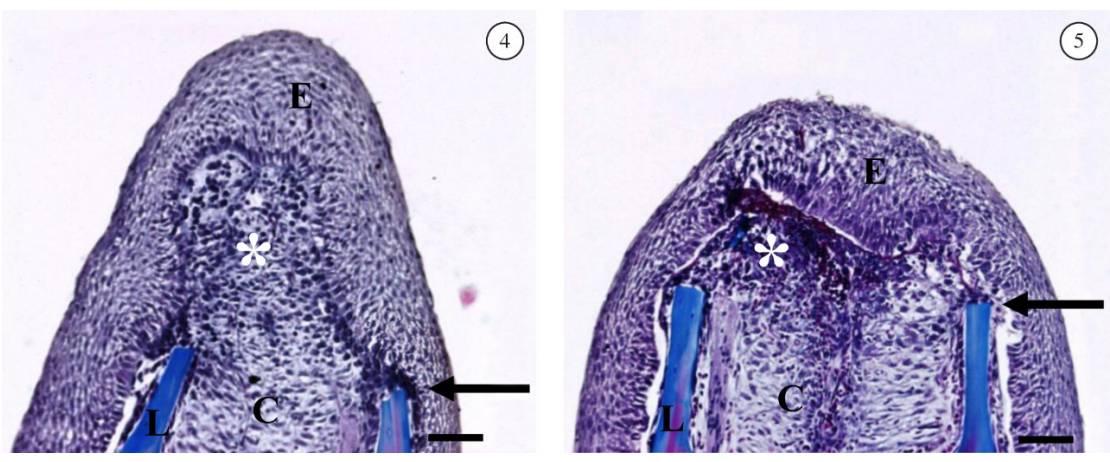

Figures 4 and 5. Longitudinal sections of distal region of Cyprinus carpio caudal fin four days after regeneration. 4. Masson's trichrome stained sections of control group. Black arrow: amputation site; L: old lepidotrichium (non-regenerated); E: epidermis in regeneration; C: non-regenerated conjunctive tissue; Asterisk: site of blastema. 5. Masson's trichrome stained sections of treated group with dexamethasone $(20 \mathrm{mg} / \mathrm{L})$. Black arrow: amputation site; L: old lepidotrichium (nonregenerated); E: epidermis in regeneration; C: non-regenerated conjunctive tissue; Asterisk: site of blastema; Bar: $50 \mu \mathrm{m}$.
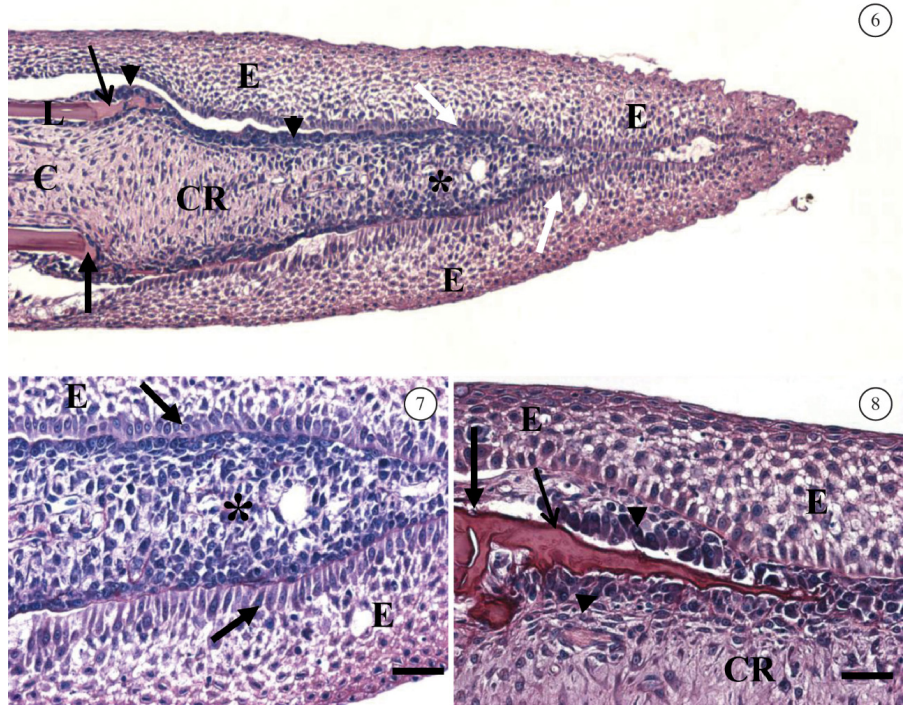

Figures 6, 7 and 8. Longitudinal sections of distal region of Cyprinus carpio caudal fin control group six days after regeneration. 6. Union of three photomicrographs (magnification: 10x). Picrosirius-hematoxylin staining; Black arrow: amputation site; Thin black arrow: lepidotrichium in regeneration; Black arrow heads: scleroblasts; L: old lepidotrichium (non-regenerated); E: epidermis in regeneration; C: non-regenerated conjunctive tissue; CR: conjunctive tissue in regeneration; Asterisk: site of blastema; White arrows: cylindrical cells of basal layer of epithelium involved in synthesis of basal membrane. 7. Greater magnification detailing cylindrical cells of basal layer of epithelium (black arrows) involved in synthesis of basal membrane after days of regeneration. Picrosirius-hematoxylin staining; E: epidermis in regeneration; Asterisk: site of blastema. 8: Greater magnification detailing scleroblasts on other side of lepidotrichium hemi-segment after days of regeneration. Picrosirius-hematoxylin staining; Black arrow: amputation site; Thin black arrow: lepidotrichium in regeneration; E: epidermis in regeneration; CR: conjunctive tissue in regeneration; Black arrow heads: scleroblasts; Bar: $50 \mu \mathrm{m}$. 

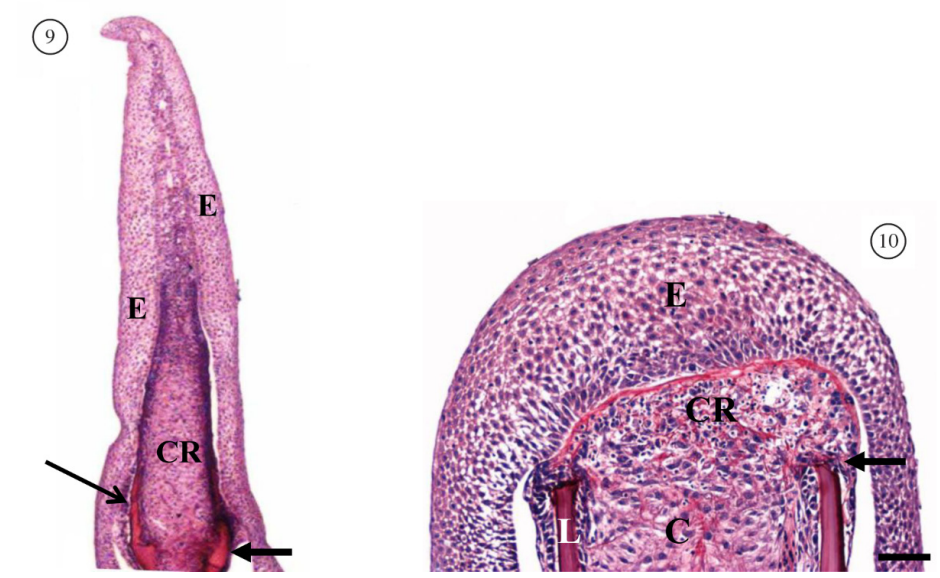

Figures 9 and 10. Longitudinal sections of distal region of Cyprinus carpio caudal fin six days after regeneration. 9. Picrosirius-hematoxylin stained sections of control group. Black arrow: amputation site; Thin black arrow: lepidotrichium in regeneration; E: epidermis in regeneration; CR: conjunctive tissue in regeneration; Bar: $200 \mu \mathrm{m}$. 10: Picrosirius-hematoxylin stained sections of treated group with dexamethasone $(20 \mathrm{mg} / \mathrm{L})$. Black arrow: amputation site; L: old lepidotrichium (nonregenerated); E: epidermis in regeneration; C: non-regenerated conjunctive tissue; CR: conjunctive tissue in regeneration; Bar: $50 \mu \mathrm{m}$.
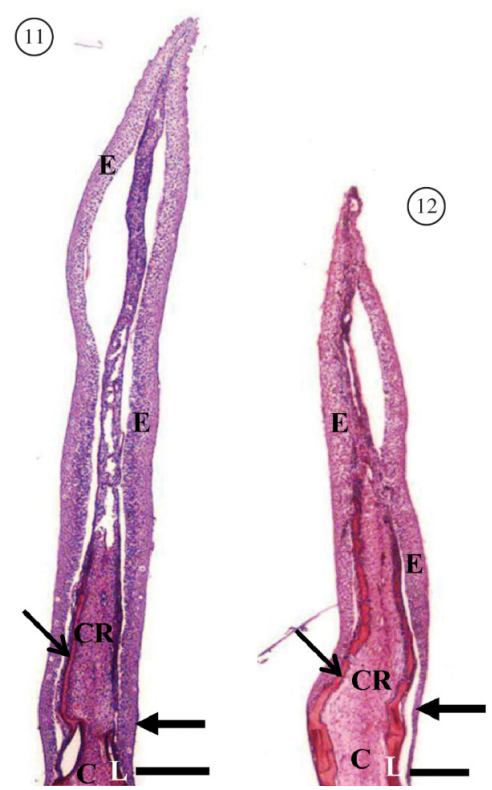

Figures 11 and 12. Longitudinal sections of distal region of Cyprinus carpio caudal fin eight days after regeneration. 11. Picrosirius-hematoxylin stained sections of control group. Black arrow: amputation site; L: old lepidotrichium (non-regenerated); Thin black arrow: lepidotrichium in regeneration; $\mathrm{E}$ : epidermis in regeneration; $\mathrm{C}$ : nonregenerated conjunctive tissue; $\mathrm{CR}$ : conjunctive tissue in regeneration. 12. Picrosirius-hematoxylin stained sections of treated group with dexamethasone $(20 \mathrm{mg} / \mathrm{L})$. Black arrow: amputation site; L: old lepidotrichium (non-regenerated); Thin black arrow: lepidotrichium in regeneration; E: epidermis in regeneration; $\mathrm{C}$ : non-regenerated conjunctive tissue; CR: conjunctive tissue in regeneration; Bar: $200 \mu \mathrm{m}$.
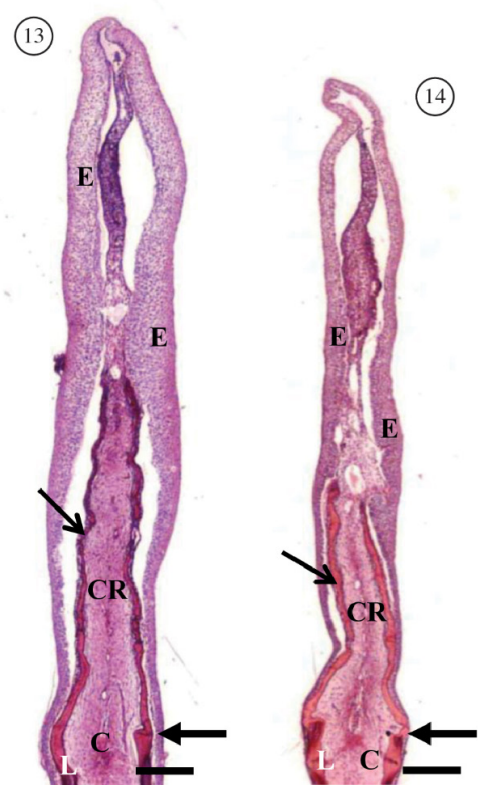

Figures 13 and 14. Longitudinal sections of distal region of Cyprinus carpio caudal fin 10 days after regeneration. 13. Picrosirius-hematoxylin stained sections of control group. Black arrow: amputation site; L: old lepidotrichium (non-regenerated); Thin black arrows: lepidotrichium in regeneration; E: epidermis in regeneration; $\mathrm{C}$ : nonregenerated conjunctive tissue; $\mathrm{CR}$ : conjunctive tissue in regeneration. 14. Picrosirius-hematoxylin stained sections of treated group with dexamethasone $(20 \mathrm{mg} / \mathrm{L})$. Black arrow: amputation site; L: old lepidotrichium (non-regenerated); Thin black arrows: lepidotrichium in regeneration; E: epidermis in regeneration; $\mathrm{C}$ : non-regenerated conjunctive tissue; CR: conjunctive tissue in regeneration; Bar: $200 \mu \mathrm{m}$. 

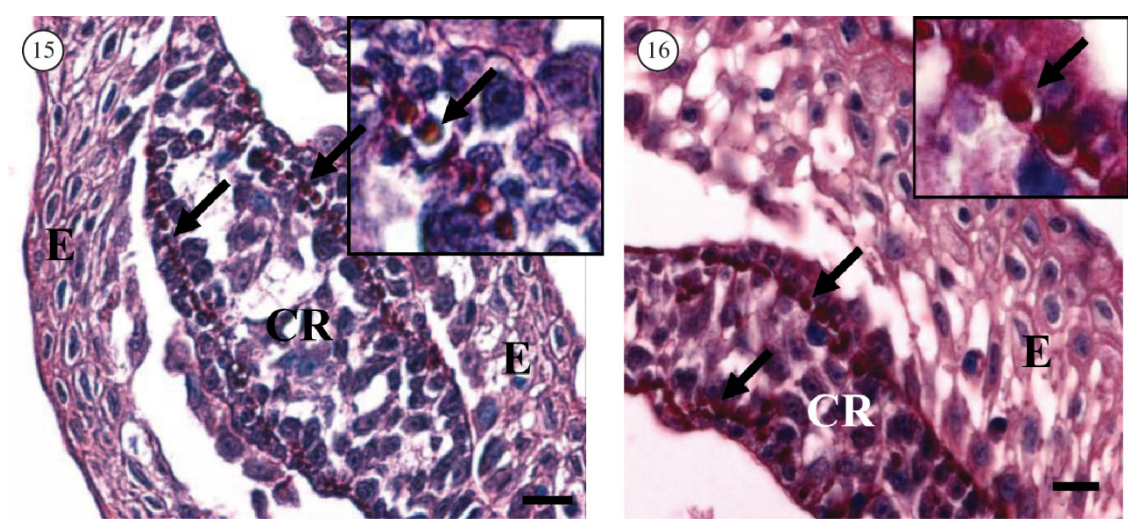

Figures 15 and 16. Cross-sections of distal region of Cyprinus carpio caudal fin 10 days after regeneration. 15. Picrosiriushematoxylin stained sections of control group. E: epidermis in regeneration; CR: conjunctive tissue in regeneration; Black arrows: actiniotrichia in regeneration. 16. Picrosirius-hematoxylin stained sections of treated group with dexamethasone $(20 \mathrm{mg} / \mathrm{L})$. E: epidermis in regeneration; CR: conjunctive tissue in regeneration; Black arrows: actiniotrichia in regeneration; Bar: $10 \mu \mathrm{m}$.

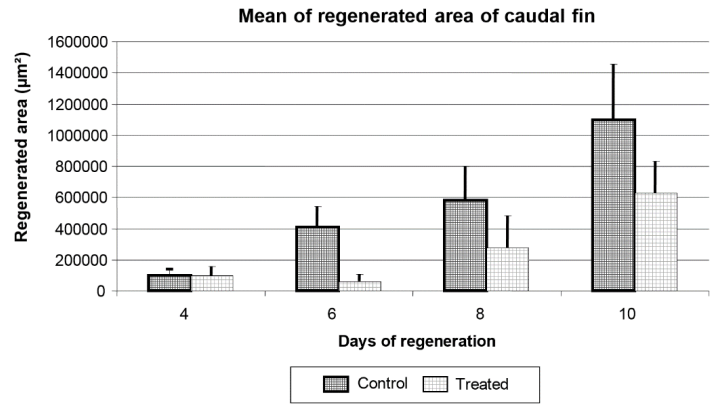

Figure 17. Mean of regenerated area of caudal fin of Cyprinus carpio from day 4 to 10 after amputation in control group and group treated with dexamethasone $(20 \mathrm{mg} / \mathrm{L})$.

The analyses of the regenerated areas measurements confirmed the macroscopy and microscopic data. The area of regenerated fin tissue in the group exposed to dexamethasone was smaller than that observed in the control group on days 4, 6, 8 and 10 (Figure 17).

Although the average of the measurements between the control and treated with 4 days regeneration has not shown statistically significant differences when the two groups were compared at intervals of 6,8 and 10 days of regeneration, the $\mathrm{P}$ value was found $<0.0001$, what demonstrates an extremely significant difference.

Thus, the morphometric and histological data reveal that the regeneration of caudal fins occurred normally in the control group, whereas the process was delayed in the group treated with dexamethasone.

\section{Discussion}

The human being is constantly subject to lesions that have healing as response, as an attempt to maintain a normal structure and function. However, some basal bodies, such as fish, have the capacity of regeneration, which is the perfect replacement of an injured cell or tissue.
Some cells or tissues are common among vertebrates in general, and this feature, along with the relatively simple anatomy of the teleost caudal fin, makes this organ a good model for studies of the regenerative capacity of tissues and organs (Kiortsis and Trampusch, 1965; Hay, 1966; Mattson, 1976; Ord and Stocken, 1984; Muneoka and Bryant, 1984; Muneoka et al., 1986; Masaki and Ide, 2007; Yin and Poss, 2008).

Although the fins of teleost fish regenerate easily in normal conditions, they are extremely sensitive to factors such as variations in temperature, light intensity and the action of some contaminants (Johnson and Weston, 1995; Nechiporuk and Keating, 2002).

Studies carried out at the Fish Bioassay Laboratory of the Department of Histology and Embryology of the Universidade Estadual de Campinas (Brazil) have demonstrated that anti-inflammatory drugs can or can not affect the synthesis of lepidotrichial collagen.

Among the drugs tested in this laboratory, aspirin was found to affect the lepidotrichia, leading to incomplete regeneration and an absence of the formation of actinotrichia (Bechara et al., 2003), whereas a study involving naproxen found no significant differences in the morphometric analysis of the regenerated area (Böckelmann and Bechara, 2004, 2007).

A number of studies have demonstrated the inhibitory effects of dexamethasone on the metabolism of conjunctive tissue in mammals. This drug accelerates the degradation of cartilage by inhibiting the proliferation of chondrocytes and formation of the extracellular matrix ( $\mathrm{Su}$ et al., 1996; Miyazaki et al., 2000). Oishi et al. (2002) found that dexamethasone strongly affected the synthesis and degradation of type I and III collagen in the dorsal skin of rats that received a daily dose of $1 \mathrm{mg} / \mathrm{kg}^{-1}$ of the drug for eight days, leading to atrophy of the skin. For this reason, since the dexamethasone is a steroid glucocorticoid drug widely used in many treatments, the effects of the chronic use of this drug on regeneration of epithelial and 
connective tissues have generated significant interest (Tenius et al., 2007).

Bechara et al. (2000) showed that, for some fish, the lepidotriquias' regeneration was poor after administrating dexamethasone (at a dosage of $0.25 \mathrm{mg} / \mathrm{L}$ ), indicating an action of this drug in the synthesis of lepidotrichial collagen.

The use of the $20 \mathrm{mg} / \mathrm{L}$ dexamethasone demonstrated that the drug increased the time required for teleost fins to regenerate, with a clear difference in the growth of the caudal fins of the treated fish in comparison to the control group. The drug slowed the regeneration process, but did not cause the complete inhibition of regeneration.

In the early regeneration process, lateral epidermal cells in the fins migrate to cover the cut surface and form an apical epidermal cap (thick layer of epithelial cells) (Böckelmann et al., 2010). The cells of the basal layer of the epidermis then undergo dimorphism from a cubic to a cylindrical shape, at which point the production of the basal membrane occurs (Böckelmann et al., 2010). Indeed, the present study observed the formation of the apical epidermal cap and cylindrical cells in the basal layer of the epidermis in both groups, with no differences between the group treated with dexamethasone and the control group until the onset of the development stage.

The mature epidermal cap is suspected to be a source of growth factors that stimulate the formation and maintenance of the function of the regenerating blastema (a proliferative mass of pluripotent progenitor cells), as there is no regeneration in the absence of the epidermal cap (Goss, 1991). Poss et al. (2000) and Nechiporuk and Keating (2002) pointed out that Fgf and Msx genes stimulate the formation of the blastema, along with the Wnt5 gene, which is detected in the epidermal cap, especially in the basal layer of the epidermis in the final stages of regeneration. The epidermis has a fundamental importance in an initial phase of wound healing with regard to the closure of the wound through cell migration and consequent protection of the fish from both biotic and abiotic factors in the surrounding environment as well as in a second dimorphic phase with regard to the regeneration of the basal membrane, thereby allowing the organization of the blastema and guidance of the regeneration process as a whole.

In the present study, the onset of the blastema formation occurred by the fourth day of regeneration in the control group. From this point onward, the reconstitution of the tissue complex occurred, involving multiple cell types, with the regeneration of the lepidotrichia (rays), actinotrichias, conjunctive tissue, blood vessel and nerves, as reported in previous studies by our group (Becerra et al., 1996, 2000, 2003; Böckelmann and Bechara, 2004, 2007). However, the same did not occur among the fish treated with dexamethasone, as the blastema remained underdeveloped after four and six days of regeneration, which explains the delay in the regeneration process in this group.

Dexamethasone possibly affected the expression of the genes necessary to the regeneration process, such as Fgf, $M s x$ or others involved in the formation of the blastema (Poss et al., 2000; Nechiporuk and Keating, 2002). The drug may also have inhibited the cells responsible for collagen synthesis, as has been reported for the lipolytic drug SU5402 and the substance 2,3,7,8-tetrachlorodibenzop-dioxin (Zodrow and Tanguay, 2003). Moreover, it may have inhibited collagen-producing cells through the inhibition of the translation of mRNA for type II collagen, as reported by Kawashima et al. (2003) in cultures cells.

At the dosage employed in the present study, dexamethasone affected the formation of the blastema and the regeneration of the fin. However, the animals treated with this drug demonstrated a gain in length of the amputated portion by day 8 , with the reestablishment of fin regeneration. One may tentatively infer that, given the response observed regarding the regeneration rate, the kinetics may be disturbed by a chemical factor, such as dexamethasone in the present case. The harm could have been repaired during the development and proliferation of the cells of the blastema, culminating in regeneration. Despite the delay, no epimorphic alterations were observed in the histological analyses.

The use of this study model contributes toward identifying the influence of an excess of corticoids over the regeneration process and collagen synthesis.

With regard to the actinotrichia, no delay occurred in the regeneration of these structures, unlike what was observed with the lepidotrichia. Therefore, these two structures must be subject to different inhibition mechanisms during their synthesis kinetics, despite the similarity between elastoidin and collagen. These aspects should be explored on the molecular level in order to determine the action of the drug.

The findings of the present study suggest that dexamethasone affected the expression of genes that are essential to the proliferation of blastema cells, thereby impairing the total regeneration of the fins. The regeneration process occurred slowly, but without complete inhibition. Thus, the caudal fin proved to be an adequate model for histological studies on regeneration and the action of drug toxicity in this process. Much is currently being studied regarding the molecular regeneration process and, in order to get a better understanding of the alterations that occur in all the phases of this process, the interaction of different types of research is of considerable importance.

\section{Acknowledgements}

The authors are grateful to Coordenação de Aperfeiçoamento de Pessoal de Nível Superior (CAPES) for financial support.

\section{References}

AKIMENKO, MA., MARÍ-BEFFA, M., BECERRA, J. and GÉRAUDIE, J., 2003. Old questions, new tools, and some answers to the mystery of fin regeneration. Developmental Dynamics, vol. 226, no. 2, p. 190-201. http://dx.doi.org/10.1002/dvdy.10248.

ARITA, GS., 1971. A re-examination of the functional morphology of the soft-rays in teleosts. Copeia, vol. 1971, no. 4, p. 691-697. http://dx.doi.org/10.2307/1442639. 
BECERRA, J., JUNQUEIRA, LCU., BECHARA, IJ. and MONTES, GS., 1996. Regeneration of fin rays in teleosts: a histochemical, radioautographic, and ultrastructural study. Archives of Histology and Cytology, vol. 59, no. 1, p. 15-35. http://dx.doi.org/10.1679/ aohc.59.15. PMid:8727360

BECERRA, J., MONTES, GS., BEXIGA, SRR. and JUNQUEIRA, LCU., 1983. Structure of the tail fin in teleosts. Cell and Tissue Research, vol. 230, no. 1, p. 127-137. http://dx.doi.org/10.1007/ BF00216033. PMid:6850759

BECHARA, IJ., BÖCKELMANN, PK., MONTES, GS. and CRUZ-HÖFLING, MA., 2003. Inhibition of caudal fin actinotrichia regeneration by acetylsalicylic acid (aspirin) in teleosts. Brazilian Journal of Morphological Sciences, vol. 20, p. 67-74.

BECHARA, IJ., JOAZEIRO, PP., MARÍ-BEFFA, M., BECERRA, J. and MONTES, GS., 2000. Collagen-affecting drugs impair regeneration of teleost tail fins. Journal of Submicroscopic Cytology and Pathology, vol. 32, no. 2, p. 273-280. PMid:11085216.

BLANC, M., 1947. Structure histologique des rayons de nageoires chez les poissons téléostéens. Bulletin de la Société Zoologique, vol. 72, p. 17-22.

BÖCKELMANN, PK. and BECHARA, IJ., 2004. Effect of naproxen on tail fin regeneration in teleost. Journal of Submicroscopic Cytology and Pathology, vol. 36, no. 1, p. 55-64. PMid:15311675.

BÖCKELMANN, PK. and BECHARA, IJ., 2007. Histochemical and ultrastructural analysis of the action of naproxen on tail fin regeneration in carp (Cyprinus carpio). Brazilian Journal of Morphological Sciences, vol. 24, no. 1, p. 17-24.

BÖCKELMANN, PK., OCHANDIO, BS. and BECHARA, IJ., 2010. Histological study of the dynamics in epidermis regeneration of the carp tail fin (Cyprinus carpio, Linnaeus, 1758). Brazilian Journal of Biology = Revista Brasileira de Biologia, vol. 70, no. 1, p. 217-223. http://dx.doi.org/10.1590/S1519-69842010000100030. PMid:20231981

GÉRAUDIE, J., 1977. Initiation of the actinotrichial development in the early fin bud of the fish, Salmo. Journal of Morphology, vol. 151, no. 3, p. 353-361. http://dx.doi.org/10.1002/jmor.1051510304. PMid:845969

GÉRAUDIE, J., 1978. The fine structure of the early pelvic fin bud of the trouts Salmo gairdneri and S. trutta fario. Acta Zoologica, vol. 59, no. 2, p. 85-96. http://dx.doi.org/10.1111/j.1463-6395.1978. tb00115.x.

GÉRAUDIE, J., MONNOT, MJ., BRULFERT, A. and FERRETTI, P., 1995. Caudal fin regeneration in wild type and long-fin mutant zebrafish is affected by retinoic acid. The International Journal of Developmental Biology, vol. 39, no. 2, p. 373-381. PMid:7669548.

GOODRICH, ES., 1904. On the dermal fin-rays of fishes - living and extinct. Journal of Microscopical Science, vol. 47, p. 465-522.

GOSS, R., 1991. The natural history (and mystery) of regeneration. In DINSMORE, CE. (Ed.). A history regeneration research. Millestones in the evolution of a science. Cambridge: Cambridge University Press. p. 7-23.

GOSS, RJ. and STAGG, MW., 1957. The regeneration of fins and fin rays in Fundulus heteroclitus. The Journal of Experimental Zoology, vol. 136, no. 3, p. 487-507. http://dx.doi.org/10.1002/ jez.1401360306. PMid:13525597

GRASSÉ, P., 1958. Rayons des nageoires. In GRASSÉ, P. Traité de zoologie. Paris: Éditions Masson. Tome XIII, Fascicule I-III. p. 731-747. Traité de Zoologie, Anatomie, Systématique, Biologie.
GUPTA, A., JAIN, GK. and RAGHUBIR, R., 1999. A time course study for the development of an immunocompromised wound model, using hydrocortisone. Journal of Pharmacological and Toxicological Methods, vol. 41, no. 4, p. 183-187. http://dx.doi. org/10.1016/S1056-8719(99)00041-6. PMid:10691024

HAY, E., 1966. Regeneration. Holt: Rinehart \& Winston. 148 p.

JOHNSON, SL. and WESTON, JA., 1995. Temperature-sensitive mutations that cause stage-specific defects in Zebrafish fin regeneration. Genetics, vol. 141, no. 4, p. 1583-1595. PMid:8601496.

KAWASHIMA, H., OGOSE, A., HAYAMI, T., YAMAGIWA, H., HATANO, H., HOTTA, T. and ENDO, N., 2003. Effect of dexamethasone on growth inhibition and chondrogenic maturation of human chondrosarcoma. Journal of Orthopaedic Science, vol. 8, no. 3, p. 341-345. http://dx.doi.org/10.1007/s10776-003-0650-y. PMid: 12768476

KEMP, NE. and PARK, JH., 1970. Regeneration of lepidotrichia and actinotrichia in the tailfin of the teleost Tilapia mossambica. Developmental Biology, vol. 22, no. 2, p. 321-342. http://dx.doi. org/10.1016/0012-1606(70)90157-0. PMid:5424983

KIORTSIS, V. and TRAMPUSCH, HAL., 1965. Regeneration in animals and related problems. Amsterdam: North-Holland Publishing Company. 568 p.

KRUKENBERG, CF., 1985. Über die chemische Beschaffenheit der sog. Hornfaden von Mustelus und uber die Zusammensetzung der Keratinosen Hollen um die Eier von Scyllium stellate. Mitt Zool Stat Neapel, vol. 6, p. 286-296.

LANZING, WJ., 1976. The fine structure of fins and finrays of Tilapia mossambica (Peters). Cell and Tissue Research, vol. 173, no. 3, p. 349-356. http://dx.doi.org/10.1007/BF00220323. PMid:991247

MABEE, PM., CROTWELL, PL., BIRD, NC. and BURKE, AC., 2002. Evolution of median fin modules in the axial skeleton of fishes. The Journal of Experimental Zoology, vol. 294, no. 2, p. 77-90. http://dx.doi.org/10.1002/jez.10076. PMid:12210109

MASAKI, H. and IDE, H., 2007. Regeneration potency of mouse limbs. Development, Growth \& Differentiation, vol. 49, no. 2, p. 89-98. http://dx.doi.org/10.1111/j.1440-169X.2007.00909.x. PMid: 17335430

MATTSON, P., 1976. Regeneration. Indianapolis: Bobbs-Merrill Company. 178 p.

MIYAZAKI, Y., TSUKAZAKI, T., HIROTA, Y., YONEKURA, A., OSAKI, M., SHINDO, H. and YAMASHITA, S., 2000. Dexamethasone inhibition of TGF beta-induced cell growth and type II collagen mRNA expression through ERK-integrated AP-1 activity in cultured rat articular chondrocytes. Osteoarthritis and cartilage /OARS, Osteoarthritis Research Society, vol. 8, no. 5, p. 378-385. http://dx.doi.org/10.1053/joca.1999.0313. PMid:10966845

MUNEOKA, K. and BRYANT, SV., 1984. Regeneration and development of vertebrate appendages. Symposia of the Zoological Society of London, vol. 52, p. 177-196.

MUNEOKA, K., HOLLER-DINSMORE, G. and BRYANT, SV., 1986. Intrinsic control of regenerative loss in Xenopus laevis limbs. The Journal of Experimental Zoology, vol. 240, no. 1, p. 47-54. http://dx.doi.org/10.1002/jez.1402400107. PMid:3772329

MURCIANO, C., PÉREZ-CLAROS, J., SMITH, A., AVARON, F., FERNÁNDEZ, TD., DURÁN, I., RUIZ-SÁNCHEZ, J., GARCÍA, F., BECERRA, J., AKIMENKO, MA. and MARÍ-BEFFA, M., 2007. Position dependence of hemiray morphogenesis during tail 
fin regeneration in Danio rerio. Developmental Biology, vol. 312 , no. 1, p. 272-283. http://dx.doi.org/10.1016/j.ydbio.2007.09.026. PMid:17977526

NECHIPORUK, A. and KEATING, MT., 2002. A proliferation gradient between proximal and msxb-expressing distal blastema directs zebrafish fin regeneration. Development, vol. 129, no. 11, p. 2607-2617. PMid:12015289.

OISHI, Y., FU, ZW., OHNUKI, Y., KATO, H. and NOGUCHI, T., 2002. Molecular basis of the alteration in skin collagen metabolism in response to in vivo dexamethasone treatment: effects on the synthesis of collagen type I and III, collagenase, and tissue inhibitors of metalloproteinases. The British Journal of Dermatology, vol. 147, no. 5, p. 859-868. http://dx.doi. org/10.1046/j.1365-2133.2002.04949.x. PMid:12410694

ORD, MG. and STOCKEN, LA. 1984. Regeneration of urodele limbs. In ORD, MG. and STOCKEN, LA. (Eds.). Cell and tissue regeneration - a biochemical approach. Canadá: John Wiley \& Sons. p. 21-37. Cell Biology: A Series of Monographs.

POSS, KD., SHEN, J. and KEATING, MT., 2000. Induction of lef1 during zebrafish fin regeneration. Developmental Dynamics : An official publication of the American Association of Anatomists, vol. 219, no. 2, p. 282-286. http://dx.doi.org/10.1002/10970177(2000)9999:9999<::AID-DVDY1045>3.3.CO;2-3. PMid:11002347

PRENANT, M., 1936. Structure fine et croissance normale des lepidotriciles articulés chez les téléostéens. Comptes Rendus des Seances de la Société de Biologie et de ses Filiales, vol. 123 , p. $474-475$.

REYNOLDS, JEF., 1996. Evaluated information on the world's drugs and medicines. In REYNOLDS, JEF. (Ed.). Martindale The Extra Pharmacopia. 31st ed. London: Royal Pharmaceutical Society. p. 1042-1043.

SANTAMARÍA, JA., MARÍ-BEFFA, M. and BECERRA, J., 1992. Interactions of the lepidotrichial matrix components during tail fin regeneration in teleosts. Differentiation; Research in Biological Diversity, vol. 49, no. 3, p. 143-150. http://dx.doi. org/10.1111/j.1432-0436.1992.tb00662.x. PMid:1377652

SU, S., DEHNADE, F. and ZAFARULLAH, M., 1996. Regulation of tissue inhibitor of metalloproteinases- 3 gene expression by transforming growth factor-beta and dexamethasone in bovine and human articular chondrocytes. DNA and Cell Biology, vol. 15, no. 12, p. 1039-1048. http://dx.doi.org/10.1089/dna.1996.15.1039. PMid:8985117

TALAS, DU., NAYCI, A., ATIS, S., POLAT, A., COMELEKOGLU, U., BAGDATOGLU, C. and RENDA, N., 2002. The effects of corticosteroids on the healing of tracheal anastomoses in a rat model. Pharmacological Research: The Official Journal of the Italian Pharmacological Society, vol. 45, no. 4, p. 299-304. http:// dx.doi.org/10.1006/phrs.2002.0964. PMid:12030793

TENIUS, FP.; BIONDO-SIMOES, MLP.; IOSHI, SO., 2007. Efeitos do uso crônico da dexametasona na cicatrização de feridas cutâneas em ratos. Brazilian Annals of Dermatology, vol. 82, no. 2.

WEIS, P. and WEIS, JS., 1980. Effect of zinc on fin regeneration in the mummichog, Fundulus heteroclitus, and its interaction with methylmercury. Fish Bulletin, vol. 78, p. 163-166.

YIN, VP. and POSS, KD., 2008. New regulators of vertebrate appendage regeneration. Current Opinion in Genetics \& Development, vol. 18, no. 4, p. 381-386. http://dx.doi.org/10.1016/j. gde.2008.06.008. PMid:18644447

YOSHINARI, N., ISHIDA, T., KUDO, A. and KAWAKAMI, A., 2009. Gene expression and functional analysis of zebrafish larval fin fold regeneration. Developmental Biology, vol. 325, no. 1, p. 71-81. http://dx.doi.org/10.1016/j.ydbio.2008.09.028. PMid:18950614

ZODROW, JM. and TANGUAY, RL., 2003. 2,3,7,8-tetrachlorodibenzop-dioxin inhibits zebrafish caudal fin regeneration. Toxicological Sciences : An Official Journal of The Society of Toxicology, vol. 76, no. 1, p. 151-161. http://dx.doi.org/10.1093/toxsci/kfg205. PMid:12915709 